THE VICEREGENCY OF

Antonio Maria Bucareli

IN NEW SPAIN, I771-I 779 
The Texas Pan-American Series 
Thb TeXas Pan-American Series is published with the assistance of a revolving publication fund established by the Pan-American Sulphur Company and other friends of Latin America in Texas. Publication of this book was also assisted by a grant from the Rockefeller Foundation through the Latin American translation program of the Association of American University Presses. 


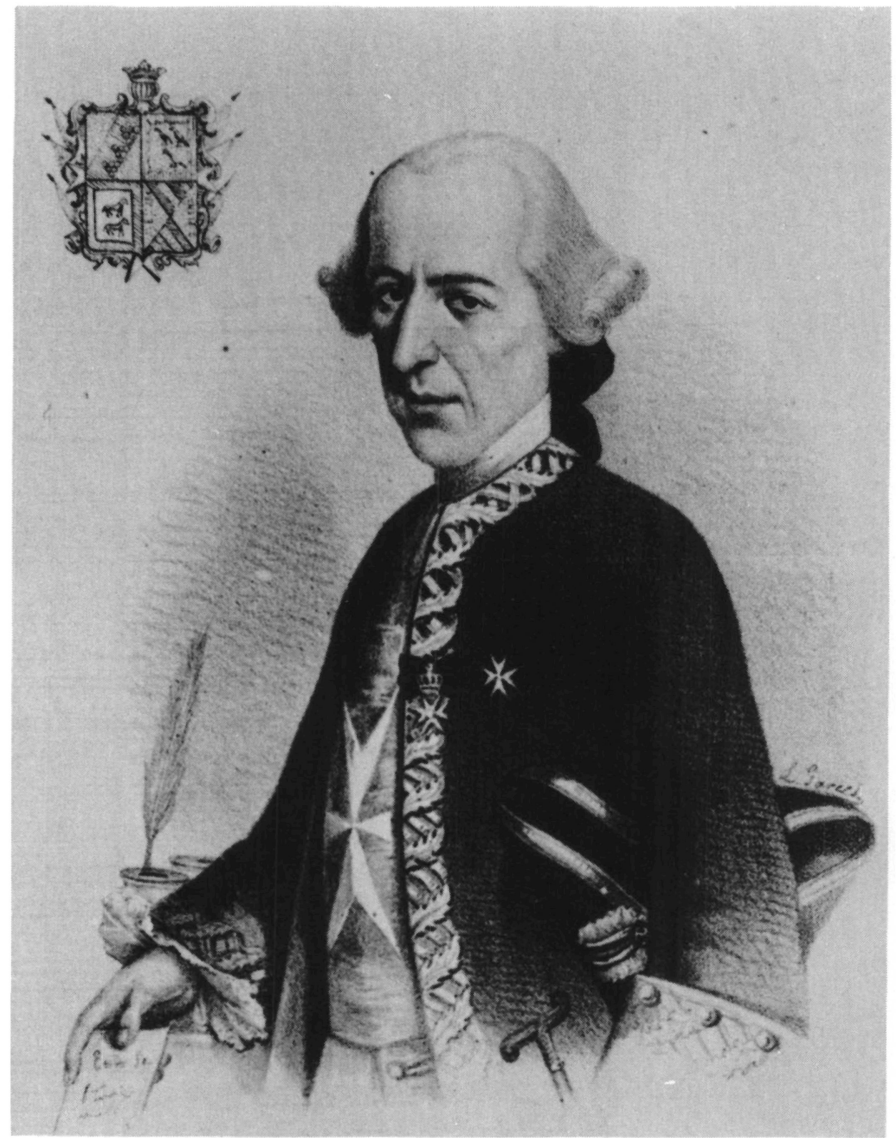

Antonio María Bucareli.

Reproduced from Manuel Rivera Cambas, Los gobernantes de México, Vol. I, p. 422. 


\section{THE VICEREGENCY OF Antonio María Bucareli IN NEW SPAIN, I77I-I779}

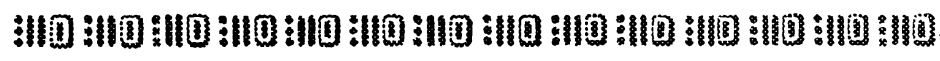

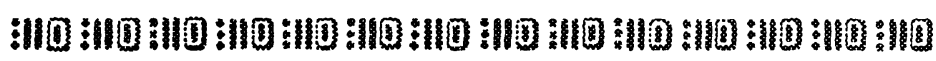
B $Y \quad B E R N A R D$ E. BO $B \quad B$ :110 :110:110 :110:Hอ :110:110 :110 :Hอ :10 :10 :10 :110:110

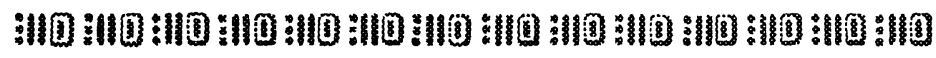

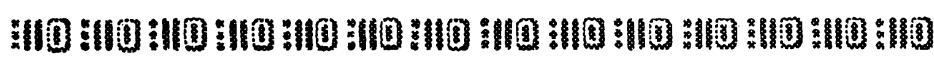
UNIVERSITY OF TEXAS PRESS - AUSTIN 
Copyright (C) I962 by Bernard E. Bobb

Copyright (C) renewed I990

First paperback printing, 2012

All rights reserved

Printed in the United States of America

Requests for permission to reproduce material from this work should be sent to:

Permissions

University of Texas Press

P.O. Box 7819

Austin, TX 78713-78I9

www.utexas.edu/utpress/about/bpermission.html

Library of Congress Catalog Number 62-009785

ISBN 978-0-292-73986-4, paperback 
TO MARNA 
THIS PAGE INTENTIONALLY LEFT BLANK 